\title{
Endoscopic Treatment of the Vesicoureteral Reflux by Electrocoagulation
}

\author{
Yasin Idweini Saed* \\ Department of Urology, Al Bashir Hospital, Amman Jordan
}

Received: June 23, 2017; Accepted: July 29, 2017; Published: August 23, 2017

*Corresponding author: Yasin Idweini Saed; Department of Urology, Al Bashir Hospital, Amman Jordan. E-mail: yasin_idweini@hotmail.com

\begin{abstract}
Purpose: We reviewed our experience with endoscopic treatment of Vesicoureteric Reflux (V.U.R) by electrocoagulation; as a simple technique to determine the efficacy and lack of morbidity of this procedure.
\end{abstract}

Material and methods: Between January 1998 and December 2002, 150 patients with vesicoureteric reflux (210 refluxing ureter) underwent 291 endoscopic electrocoagulation in the hemitrigone in order to treat the reflux. Male to female ratio was 2:8. Age ranged from 2 months to 47 years, median: 7 years. Localization was bilateral 39\% Rt. Side 20\%, Lt Side $41 \%$. The grade of vesicoureteric reflux ranged from 2 to 5 th grade. Secondary reflux was in $18 \%$ of the cases.

Results: Good results achieved in $85 \%$ of patients, $25 \%$ of the patients underwent repeated coagulation (2-3 times). 12\% underwent surgical treatment because of the associated abnormalities (paraureteral vesical diverticulum, ectopic ureterocele, posterior urethral valves, ureteral duplication etc.).

Conclusions: Endoscopic treatment of V.U.R. by electrocoagulation is a simple and safe procedure, with less morbidity, and it is cost effective.

Key Words: Vesicoureteric Reflux; Electrocoagulation; Endoscopic Treatment

\section{Introduction}

Vesicoureteric Reflux (V.U.R) indicates the retrograde flow of urine into the upper urinary tract. The overall incidence of reflux in normal children ranges from $1 \%$ to $18 \%$. Reflux is found in up to $70 \%$ of infants who present with urinary tract infection [1].

The vast majority (85\%) of reflux occurs in female [2]. Males who present with urinary infection have a higher likelihood of having the anomaly. Primary reflux is congenital anomaly of the ureterovesical junction in which a deficiency of the longitudinal muscle of the intravesical ureters, results in an inadequate valvular mechanism. In one study a 5:1 ratio of tunnel length to ureteral diameter was found in normal children without reflux [3]. Reflux occurs when the intravesical (intramural) ureteral length is too short. Secondary reflux is that caused by bladder obstruction and its consequent elevated pressures [4].

Familial reflux is common, being present in about one third of the siblings, in some studies, sibling reflux rate reached about 51\%, [5]. Vesicoureteral reflux may damage the kidney by repeated introduction of infected urine into the kidneys or by hydrostatic pressure on the renal tissue causing reflux nephropathy, which could be detected by urinary cytokines as a nephropathy marker [6].

\section{Objectives}

Objectives of this study were introduction and evaluation of electrocoagulation treatment of V.U.R.

Selection of proper patients, and determination of its efficacy.
Comparison with other historical techniques and other authors.

Determination of further complementary techniques to do in case of failure.

\section{Materials and Methods}

Between January 1998 and December 2002, 150 patients with (V.U.R) (210 refluxing ureter) underwent consequence 291 endoscopic electrocoagulation in the hemitrigone in order to treat the reflux. The patient is placed in the dorsal lithotomy position, cystoscopy is performed and the ureters are visualized, a cautery probe is advanced through the working channel, electrocoagulation is done in a limited zone of the hemitrigone, distal to the ureteral orifice of the refluxing ureter, in rhomboid shape between the ureteric orifice and the bladder neck,(about $1 \mathrm{~cm}$ square space).The electrocoagulation done by fine probe making superficial electrocoagulation dots in the mucosa of the mentioned limited zone in the trigone [Figure 13-16]. Foleys catheter is inserted at the end of the procedure to avoid bladder distention in order to enhance rapid healing of coagulated zone in the trigone; the length of procedure is less than 15 minutes. The patient is discharged from hospital the next day after removing Foleys catheter, keeping the patient on prophylactic antiseptic for 3 months, after that a Voiding Cystourethrogram (V.C.U.G) is done for follow up. Male to female ratio was 2:8. Age ranged from 2 months to 42 years, (median 7 years.). Localization was: bilateral 39\%, RT side $20 \%$, Lt Side 41\%. Grading was GII: 35\%, GIII: 33\% GIV: 23\%, GV: 9\%.

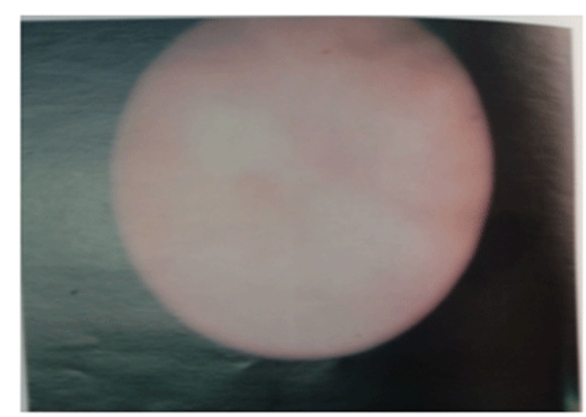

Figure 13: Preoperative cystoscopic view of refluxing ureteric orifice

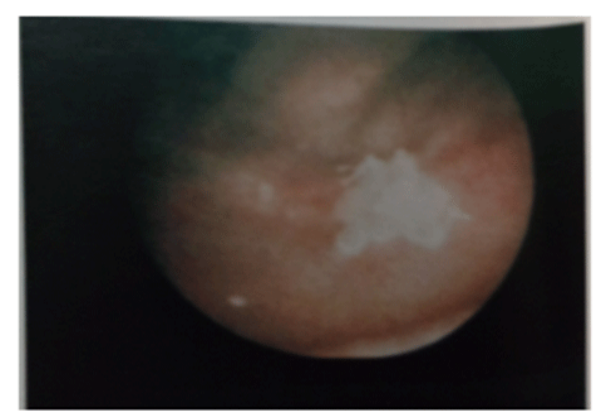

Figure 14: Postoperative cystoscopic view of refluxing ureteric orifice after electrocoagulation 


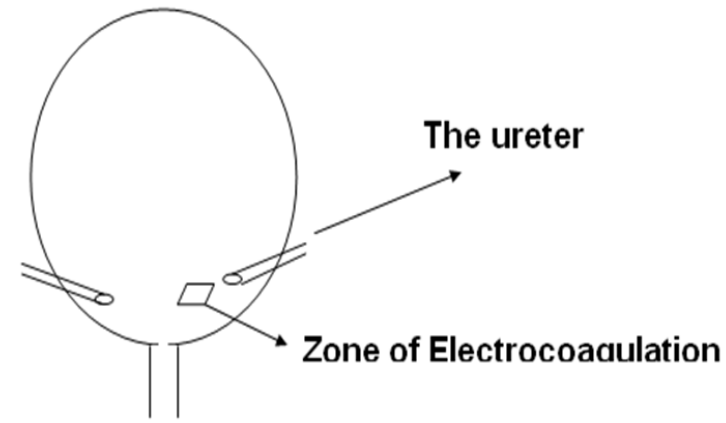

Figure 15: Electrocoagulation

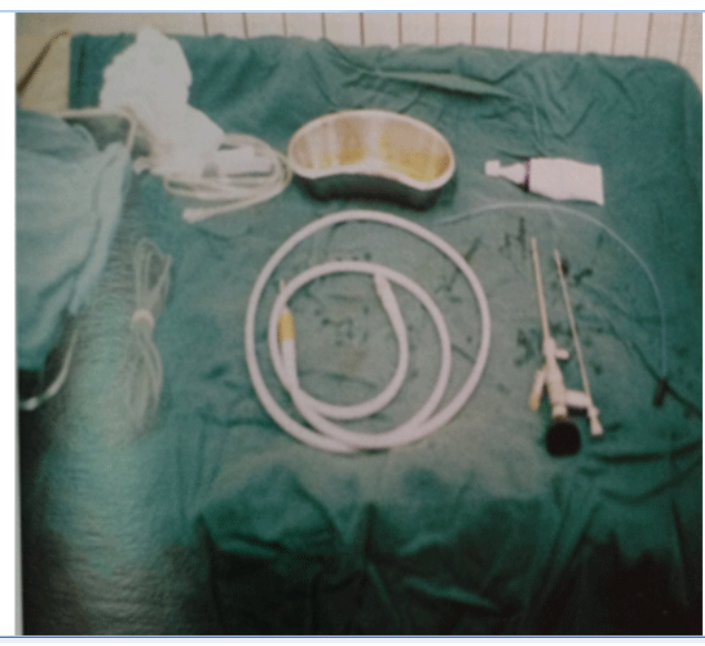

Figure 16: Material: Pediatric cystoscope and electrode probe

\section{Classification of patients}

\begin{tabular}{|c|c|}
\hline \multicolumn{1}{|c|}{ Glassification of patients } & Patients \\
\hline I. Primary V.U.R & 124 \\
\hline II. Secondary V.U.R & 26 \\
\hline (II A) Neurogenic bladder & 8 \\
\hline (II B) Associated to another anomalies & 18 \\
\hline Posterior urethral valves & 2 \\
\hline Stricture urethra & 1 \\
\hline Ureterocele + duplication & 2 \\
\hline Ureteral duplication & 4 \\
\hline Paraureteral diverticulum & 1 \\
\hline Recurrent reflux after pregnancy & 2 \\
\hline Non functioning kidney due to severe V.U.R & 2 \\
\hline Ectopic ureter with severe V.U.R & 1 \\
\hline
\end{tabular}

Citation: Yasin Idweini S (2017) Endoscopic Treatment of the Vesicoureteral Reflux by Electrocoagulation.) Urol Nephrol Open Access 3(3): 1-6. DOI: $10.15226 / 2473-6430 / 3 / 3 / 00133$

\section{Classification and treatment}

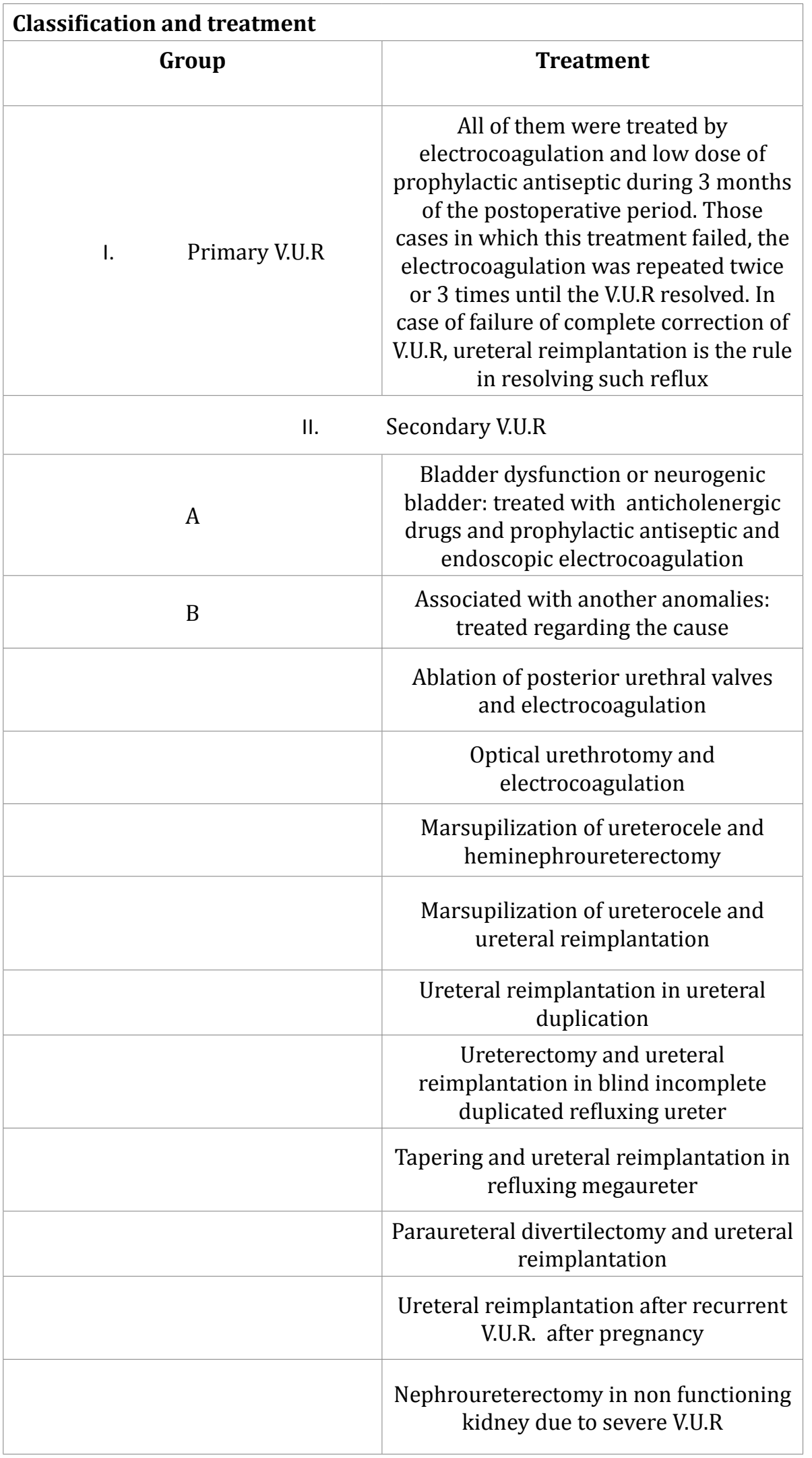

\section{Results}

In $85 \%$ of patients good results were achieved, $25 \%$ of the patients needed repeated coagulation (2-3 times) (Table 1) (Table 2). 12\% underwent surgical treatment ( ureteral reimplantation, paraureteral vesical divertilectomy, heminephroureterectomy, marsupilization of a ureterocele, ablation of posterior urethral valves... etc), because of the presence of associated abnormality as vesical diverticulum and saccules near the ureteric orifices, ureterocele, posterior urethral valves ... etc) with good results .

Patients were followed up to five years including urine culture quarterly, and radiologic studies every two years, low dos prophylactic antiseptic were continued until the reflux resolved as expected. When present, bladder dysfuncion should be treated with anticholenergics. 
Table 1 Result of treatment of V.U.R by Electrocoagulation and evolution of complications in each group.

We divide the patient in 5 groups regarding the associated pathology

\begin{tabular}{|c|c|c|c|c|c|c|c|c|c|}
\hline \multirow{3}{*}{ Group } & \multirow{3}{*}{ Cases } & \multirow{3}{*}{$\begin{array}{c}\text { Number } \\
\text { of } \\
\text { ureters }\end{array}$} & \multicolumn{4}{|c|}{ Complications } & \multirow{2}{*}{\multicolumn{3}{|c|}{ Good Result }} \\
\hline & & & \multicolumn{2}{|c|}{ Recurrence } & \multicolumn{2}{|c|}{$\begin{array}{c}\text { Contralateral } \\
\text { V.U.R. }\end{array}$} & & & \\
\hline & & & $\mathbf{n}$ & $\%$ & $\mathbf{n}$ & $\%$ & $\mathbf{n}$ & $\%$ & \\
\hline \multirow{2}{*}{$\begin{array}{l}\text { (I) primary } \\
\text { V.U.R. }\end{array}$} & \multirow{2}{*}{124} & \multirow{2}{*}{177} & 30 & 17 & 1 & 0.6 & 147 & 83 & * \\
\hline & & & 12 & 7 & 0 & 0 & 165 & 93 & ** \\
\hline \multirow{2}{*}{$\begin{array}{l}\text { (II) } \\
\text { Duplication } \\
\text { complete or } \\
\text { incomplete }\end{array}$} & \multirow{2}{*}{6} & \multirow{2}{*}{10} & 8 & 80 & 0 & 0 & 2 & 20 & * \\
\hline & & & 8 & 80 & 0 & 0 & 2 & 20 & ** \\
\hline \multirow{2}{*}{$\begin{array}{c}\text { (III) } \\
\text { Neurogenic } \\
\text { bladder }\end{array}$} & \multirow[t]{2}{*}{8} & \multirow[t]{2}{*}{9} & 2 & 22 & 0 & 0 & 7 & 77 & * \\
\hline & & & 0 & 0 & 0 & 0 & 9 & 100 & ** \\
\hline \multirow{2}{*}{$\begin{array}{c}\text { (IV) } \\
\text { Megaureter }\end{array}$} & \multirow{2}{*}{1} & \multirow{2}{*}{1} & 1 & 100 & 0 & 0 & 0 & 0 & * \\
\hline & & & 1 & 100 & 0 & 0 & 0 & 0 & ** \\
\hline \multirow{2}{*}{$\begin{array}{l}\text { (V) other } \\
\text { pathology }\end{array}$} & \multirow{2}{*}{11} & \multirow{2}{*}{13} & 11 & 85 & 0 & 0 & 2 & 15 & * \\
\hline & & & 10 & 77 & 0 & 0 & 3 & 23 & ** \\
\hline \multirow{2}{*}{ Total } & \multirow{2}{*}{150} & \multirow{2}{*}{210} & 52 & 25 & 0 & 0 & 157 & 75 & $*$ \\
\hline & & & 31 & 15 & 0 & 0 & 178 & 85 & ** \\
\hline
\end{tabular}

* Revision at 3 months after treatment by electrocoagulation.

** Revision at 6 or 9 months after 2 o 3 episodes of electrocoagulation.

Table 2 Comparative study between the surgical and endoscopic treatment of V.U.R by subureteral injection or electrocoagulation in several international publications

\begin{tabular}{|c|c|c|c|c|}
\hline Author & Kind of treatment & $\begin{array}{c}\text { N. of } \\
\text { patients }\end{array}$ & $\begin{array}{l}\text { N. of } \\
\text { Ureters }\end{array}$ & $\begin{array}{l}\text { Successful } \\
\text { rate\% }\end{array}$ \\
\hline \multirow{2}{*}{$\begin{array}{c}\text { Carpentier (7) (J. } \\
\text { Urology 1982) }\end{array}$} & $\begin{array}{l}\text { Politano-Lead } \\
\text { Better. }\end{array}$ & & 100 & 88.0 \\
\hline & Cohen technique & & 100 & 97.0 \\
\hline $\begin{array}{l}\text { Moragues, Sanroman. } \\
\text { Ibarra } \\
\text { (Actas Urol. Esp. 1988) } \\
\text { (8) }\end{array}$ & Cohen Technique & 359 & 581 & 95.52 \\
\hline $\begin{array}{c}\text { Puri, Merckx } \\
\text { ( Br. J. Urol. 1995) } \\
(9,10)\end{array}$ & Teflon injection & 4234 & 6316 & 75.9 \\
\hline $\begin{array}{l}\text { Stenberg y lacgkren } \\
\text { ( J. Urol. 1995) (11) }\end{array}$ & Deflux injection & 75 & 101 & 68.0 \\
\hline $\begin{array}{l}\text { Chancellor. Palma } \\
\text { (J.A.M. 1994) } \\
\text { Urol. 1994) }(12,13)\end{array}$ & $\begin{array}{l}\text { Autologus } \\
\text { Fat injection }\end{array}$ & 19 & 29 & 22.6 \\
\hline $\begin{array}{l}\text { Diamond, Caldamone } \\
\text { ( Pediatrics Suppl. } \\
\text { 1998) (14) }\end{array}$ & $\begin{array}{l}\text { Chondrocytes } \\
\text { injection }\end{array}$ & 29 & 50 & 60.0 \\
\hline $\begin{array}{c}\text { Gotz Frigyes, Buzogany } \\
\text { Kincses, Vera. } \\
\text { (Lege Artis Med.1991) } \\
\text { (15) }\end{array}$ & Electrocoagulation & 11 & 13 & 100.0 \\
\hline $\begin{array}{l}\text { Yasin Idweini Saed. } \\
\text { (Arab Journal of } \\
\text { Urology 2003) (21) }\end{array}$ & Electrocoagulation & 88 & 121 & 79.0 \\
\hline Our study & Electrocoagulation & 150 & 210 & 85.0 \\
\hline
\end{tabular}

Relations of recurrent vesicoureteral reflux in ureters regarding to the age of patient.

\begin{tabular}{|c|c|c|c|}
\hline Age ( years ) & N of ureters & \multicolumn{2}{|c|}{ Recurrent V.U.R. } \\
\hline$<\mathbf{1}$ & & $\mathbf{N}$ & $\mathbf{\%}$ \\
\hline $\mathbf{1 - 5}$ & 25 & 4 & 16 \\
\hline$<\mathbf{5}$ & 94 & 13 & 13.8 \\
\hline Total & 91 & 14 & 15.3 \\
\hline
\end{tabular}

\section{Discussion}

For long time surgery was the only method of treatment of V.U.R. in failure of medical treatment. Recently less invasive techniques were suggested to correct the V.U.R. endoscopically with acceptable results. This study was justified by the impact of the disease on the patients with its morbidity and to find a minimal invasive method for the treatment of V.U.R.

As the electrocoagulation is a simple, successful, durable and minimally invasive procedure, it was chosen for the treatment of the patients avoiding the use of long- term prophylactic urinary antiseptics and periodic radiographic follow- up. Moreover, the time required for conservative therapy is shortened.

This treatment of electrocoagulation was performed early in Hungary by professor Gotz Frigyes et al, and had excellent results [15].

Our patients previously were treated and followed up by the pediatrician and referred to our clinic seeking further treatment.

All patients were treated initially by endoscopic electrocoagulation in a limited zone of the hemitrigone of the ipsilateral refluxing ureter followed by low dose prophylactic antiseptics until reflux resolved, some of them (25\%) needed repeated electrocoagulation (2-3 times), only limited cases $(12 \%)$ failed and needed surgical treatment, i.e. ureteral reimplantation because of the associated congenital abnormality at the ureterovesical junction (bladder diverticulum, duplication ureter ... etc).

Hutch, Bunge and flocks suggested that the trigone (which originates in the ureter and inserts in the verumontanum) contracts during voiding, when intravesical pressure is at its maximum, thus pulling additional intravesical ureter into the bladder [16].

On this basis, it seems that after the treatment of reflux by electrocoagulation, fibrosis occurs in the hemitrigone after healing causing a pull of the ureter down more caudally, increasing the length of intravesical ureter, and antirreflux mechanism leading to reflux prevention. We recommend the wide ranging application of this technique, and this method does not influence the conditions for a potential anti -reflux plastic surgery [15].

In our study we found that the group of primary V.U.R. Grade $1-1 \mathrm{~V}$ is ideal for this technique ( $93 \%$ success rate), and the group of neurogenic bladder also had good results $(100 \%$ success rate) in addition to the anticholenergic treatment.

Previos urodynamic evaluation was done for patient where a secondary cause of reflux was suspected.

We revised our patients 3,18 and 36 months after electrocoagulation (all patients were revised on the first revision at 3 months after electrocoagulation, 78 patients (112 ureteres) on the second revision at 18 month after electrocoagulation, 24 patients (34 ureteres) after 3 years of the first electrocoagulation. 
The success of the treatment by electrocoagulation increased on the second revision because of $25 \%$ of patients needed ( 2 or 3 ) episodes of electrocoagulation to completely correct the V.U.R.

Follow up included ecography, urography and micturating cystogram which based on the appearance of contrast in the ureter and upper collecting system (Figure 1-12).

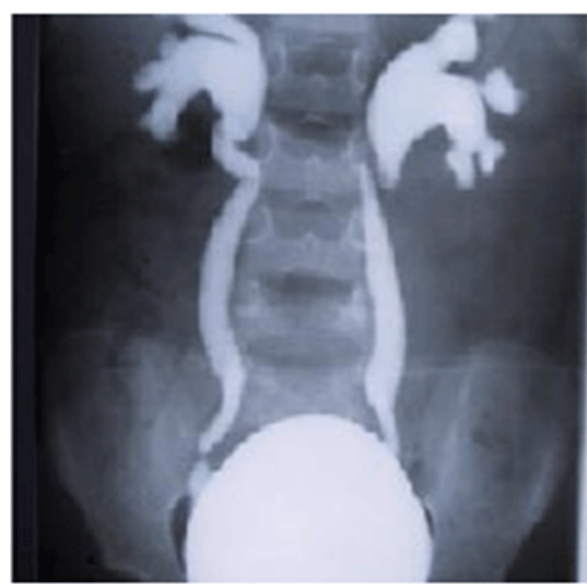

Figure 1: M.C.U.G.: Bil. V.U.R.
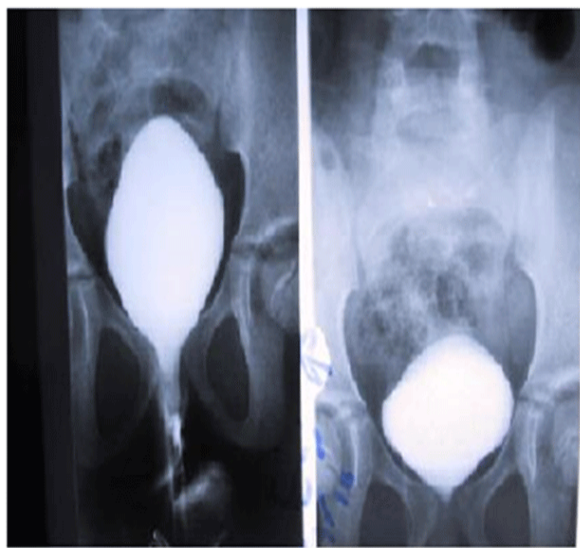

Figure 2:M.C.U.G. post. Electrocoag: Reflux corrected.

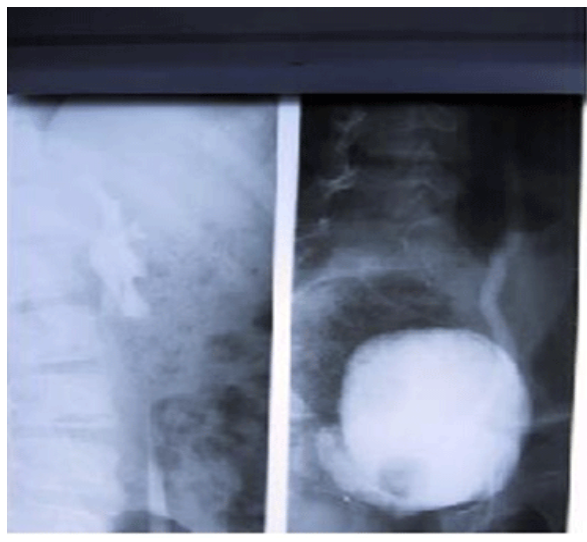

Figure 3: M.C.U.G: Lt.V.U.R

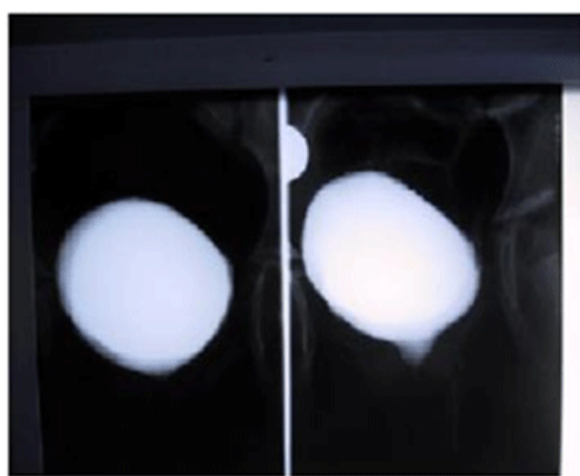

Figure 4: Electrocoagulation M.C.U.G.: Reflux corrected.

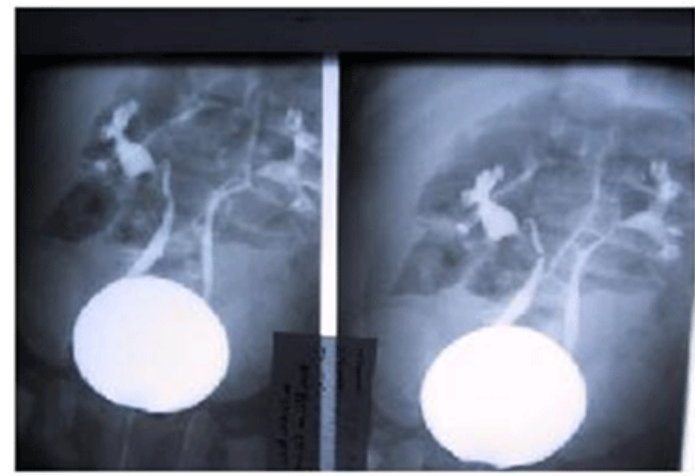

Figure 5: M.C.U.G: Bil. V.U.R.

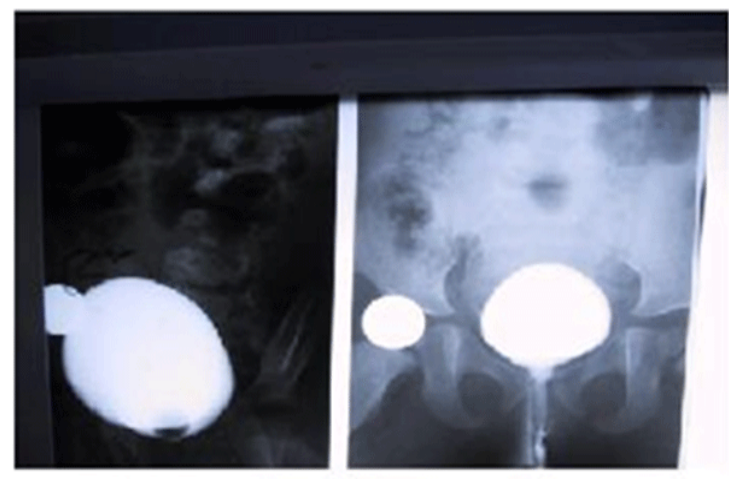

Figure 6: Post. Electrocoagulation M.C.U.G: Reflux Corrected

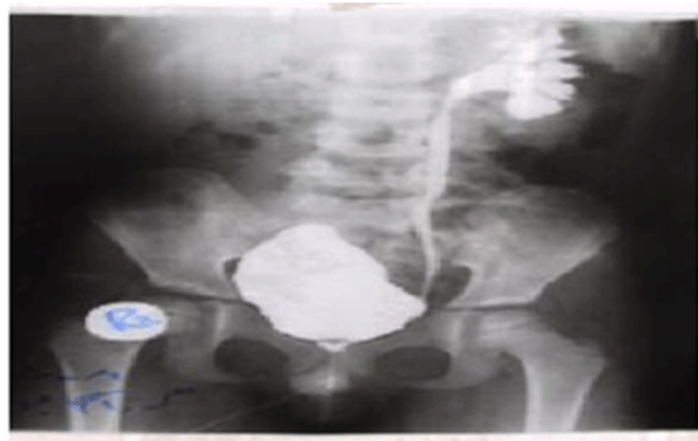

Figure 7: M.C.U.G Secondary Lt V.U.R (Neurogenic bladder).

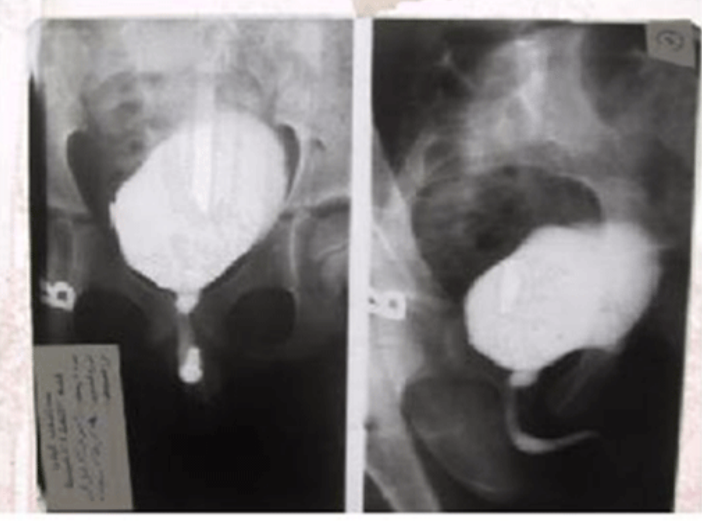

Figure 8: Post Electrocoagulation V.U.R. Corrected 


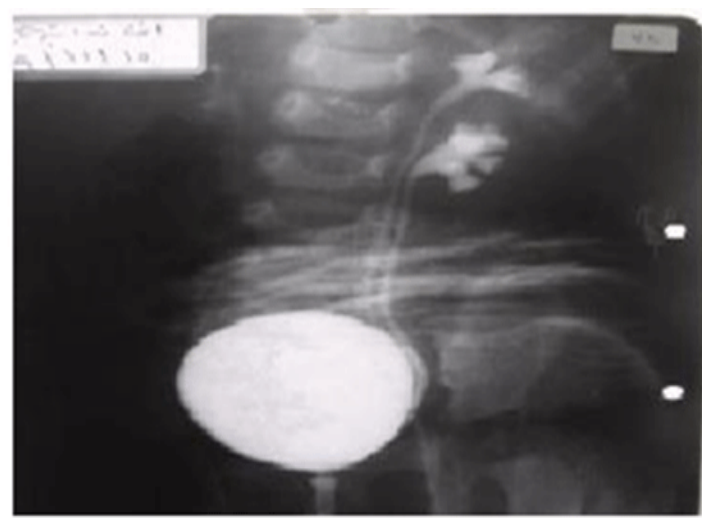

Figure 9: M.C.U.G.: V.U.R in duplicated Lt Ureter.

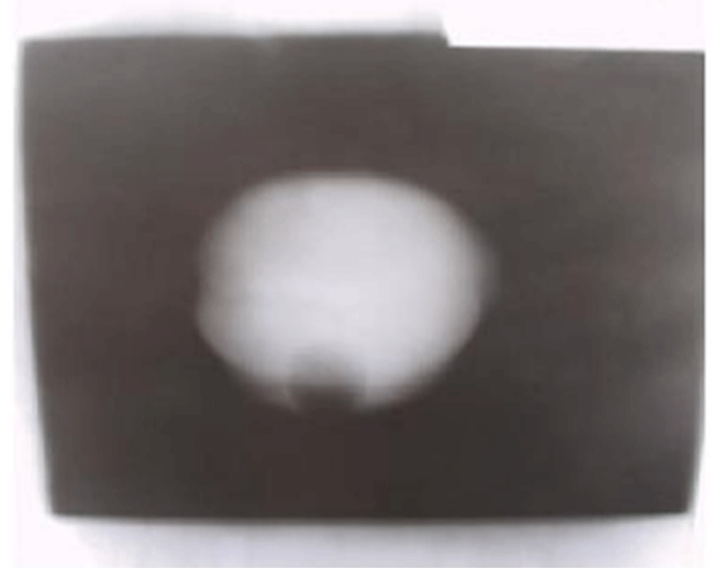

Figure 10: Post. Electrocoagulation M.C.U.G: V.U.R. corrected.

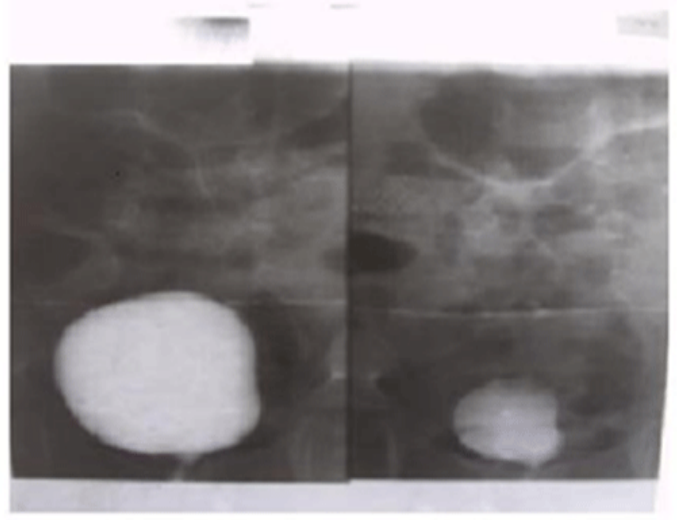

Figure 11: Post Electrocoagulation M.C.U.G. (Voiding phase) V.U.R corrected

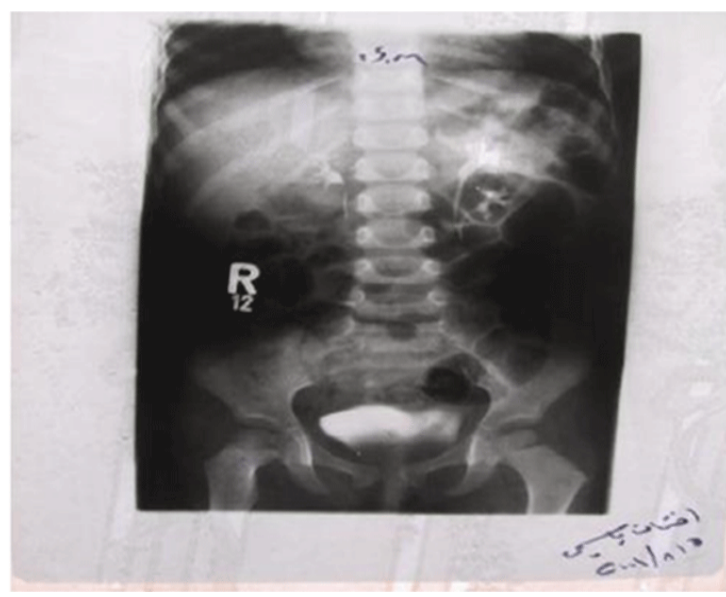

Figure 12: Post ElectrocoagulationI.V.U: Normal urogram.
We had one case of contralateral V.U.R. which was resolved at 6 months conservatively.

Those cases associated with congenital abnormalities (duplication, ureterocele, diverticulum ....etc.), which did not respond to the electro coagulation, were treated surgically with good results $(100 \%$ of success rate).

Open surgery has a success rate of $97 \%$ and the disadvantages are: long hospital stay, increased morbidity, high cost, and cosmotic means [7].

Endoscopic injection of certain materials behind the ureters (Teflon, collagen ... etc.) still have high morbidity, little efficacy and formation of antibodies cloms and migrate [17-20].

\section{Conclusion}

Electrocoagulation treatment of V.U.R is:

-Simple, minimally invasive, durable, cost effective, less morbidity and effective.

-Has excellent results in cases of primary V.U.R. (grade I, II, III, IV).

-Is effective in the treatment of secondary V.U.R. due to bladder dysfunction and certain types of neurogenic bladder in addition of anticholenergic treatment.

-It is not effective in the treatment of V.U.R when it is associated with another anomalies ( Paraureteral Diverticulum, ureterocele, some cases of duplicated ureter).

-It could be an alternative to surgery.

\section{References}

1. Baker R, Maxted W, Maylath J, Shuman I. Relation of age, sex, and infection to reflux: Data indicating high spontaneous cure rate in pediatric patients. J Urol. 1966;95(1):2732 .

2. Shopfner CE. V.U.R. five years re- evaluation. Radiology. 1970;95:637.

3. PAQUIN AJJr. Ureterovesical anastomosis: the description and evaluation of a technique. J Urol. 1959;82:573-583.

4. Henneberry MO, Stephens FD. Renal hypoplasic and dysplasia in infants with posterior uretheral valves. J Urol. 1980;123(6): 912. doi:- 10.1016/S0022-5347(17)56190-X

5. Parekh DJ, Pope JC, Adams MC, Brock JW. Outcome of sibling vesicoureteral reflux. J Urol. 2002;167(1):283-284.

6. Ninan GK, Jutley RS, Eremin O. Urinary cytokines as markers of reflux nephropathy. J Urol. 1999 Nov;162(5):1739-1742.

7. Carpentier PJ, Bettink PJ, Hop WGJ. A retrospective study of 100 ureteric implants by the politano- lead better method and 100 by the Cohen technique for reflux prevention. Aktuel Urol. 1975:6:1.

8. E. Moragues, G. Sanroman Vila, Garcia Ibarra. Ureter- cistoneostomia antirreflujo segun tecnica de Cohen.A proposito de 581 reimplantaciones. Actas Urol. Esp. vol X11-2, 111118, 1988.

9. Puri P. Ten year experience with subureteric Teflon injection (STING) in the treatment of V.U.R. Br J. Urol. 1995;75(2):126-131. doi: 10.1111/j.1464-410X.1995.tb07296.x

10. Merckx L, De Boe V, Braeckman J, Verboven M, Piepsz A, Keuppens F. Endoscopic submucosal Teflon injection (STING): an alternative treatment of vesicoureteric reflux in children. Eur J Pediatr Surg. 1995;5(1):34-36. doi: 10.1055/s-2008-1066159

11. Stenberg A, Läckgren G. A new bioimplant for the end oscopic treatment of vesicoureteral reflux: experimental and short-term clinical results. J Urol. 1995;154(2 Pt 2):800-803.

12. Chancellor MB, Rivas DA, Liberman S.N, Moore J, Staas EW. Cystoscopic autogenous fat injection treatment of vesicoureteral reflux in spinal cord injury. J AM paraplegia soc. 1994;17(2):50-54. doi: 10.1080/01952307.1994.11735916

13.Palma PC, Ferreira U, Ikari O, Rodrigues Netto N Jr. Subureteric lipoinjection for vesicoureteral reflux in renal transplant candidates. Urology. 1994;43(2):174-177.

14. Diamond DA, Caldamone AA. Endoscopic correction of vesicoureteral reflux in children using autologous chondrocytes: preliminary results. J Urol. 1999;162(3 Pt 2):1185- 
1158.

15.Gotz Frigyes, Buzogany Istvan, Jasai Vera, Kincses Istvan. Endoscopic Treatment of Vesicoureteral Reflux. Lege Artis Medicinae. 1991;1(4):240- 245.

16. Hutch JA, Bunge RG, Flocks RH. Vesicoureteral reflux in children. J. Urol. 1995;74:607.

17.Mittleman RE, Marraccini JV. Pulmonary Teflon granulomas following periurethral Teflon injection for urinary incontinence. Arch Pathol Lab Med. 1983;107(11):611612.

18. Katsumi inoue, Takahisa Nakamoto, Akibur Usui et al: Evaluation of antibody cloms in response to endoscopic subureteral collagen injection in patients with vesicoureteral reflux. The J of Urol. 2001.165.533-558.
19. Michael P. Leonardo, Allon Dector, Kevin Hills, Lawrence W. Mix. Endoscopic subureteral collagen injection: are immunologic concerns justified? The J. of urology. 1998;160(3):1012-1016. doi:10.1016/S0022-5347(01)62684-3

20. Aragona F, D’Urso L, Scremin E, Salmaso R, Glazel GP. Polytetrafluoroethylene giant granuloma and adenopathy: long-term complications following subureteral polytetrafluoroethylene injection for the treatment of vesicoureteral reflux in children. J Urol. 1997;158(4):1539-1542.

21.Yasin Idweini Saed. Endoscopic Treatment of the V.U.R. Arab Journal of Urology. 2003;1(3):55-58. 